\title{
Tahuri: The Model of Christian and Muslim Peace in the Tehoru and Telutih Districts
}

\author{
Resa Dandirwalu \\ Lecturer of Theology Faculty of Christian University of Indonesia, Maluku, St. OT Pattimaipaiuw Ambon \\ Handry Yance Rehy \\ Pastor of the Maluku Protestant Church, St. Mayor Jeneral in Panjaitan, Ambon
}

\begin{abstract}
This research aims to establish a model of peace between Christians and Moslems in Telutih and Tehoru district based on the local culture. According to the qualitative analysis, the result showed that the model of peace after the conflict in January $19^{\text {th }}, 1999$, done by the Christians and Moslems in Telutih and Tehoru district was strengthened and revived the symbols of local culture which became the norm for living together in a society. One of them was tahuri. This symbol was taken from the symbol of Souupaa Maraina which means the mandate to the descendants of Nusa Ina (Christians and Moslems) to deliver the message of brotherhood/sisterhood toward the others in order to create and to concrete the peaceful life. Through the symbol of tahuri, the peace can be brought among the Christians and Moslems in Telutih and Tehoru district after the conflict in January $19^{\text {th }}, 1999$ and can be preserved until now. Hence, the local culture is totally relevant and operational to be used as an alternative model to create and to concrete peace in the life of plural society in the Maluku Province and in The Unitary State of the Republic of Indonesia.
\end{abstract}

Keywords: Tahuri; Model; Peace; Christian; Moslem

DOI: $10.7176 /$ RHSS/10-10-05

Publication date:May $31^{\text {st }} 2020$

\section{A. INTRODUCTION}

Before the 1999 conflict, people in Tehoru and Telutih Districts lived in peace and brotherhood because they made local wisdom such as pela, gandong, masohi, eating patita as a common norm without discriminating against religious background, so the construction of the mosque was always assisted by the Christian. On the contrary, the construction of Church Building was assisted by Moslem. ${ }^{1}$

The peace and brotherhood were fractured as the result of the 1999 social conflict in Ambon City, which also impacted to the villages in Tehoru and Telutih Districts. Society in Christian villages, such as: Saunulu, Salamahu, Lafa, Maneoratu, Laha, Ulahahan, Yamalatu, and Hunisi, had to evacuate to the North West Seram forest and settle there, some of them were evacuated to Teon Nila Serua (TNS) District, Amahai, and Makariki to save themselves as the result of the social conflict.

After the social conflict in 1999, society from Christian villages tried to return to their villages in Tehoru and Telutih districts, so in 2006 some people returned to their villages. The reconciliation process continued with the Central Maluku Government, so in 2008, society from Christian villages had returned to their villages to organize their live. The construction of the Church Building was carried out with the help of Inpres (Presidential Instruction) fund Number 06 year 2006, so in 2008 Christian villages had inaugurated their Church Building as a place of worship for Jesus Christ.

Christian society who have returned to their villages, still felt worry, anxious, fear, and insecurity because their return process only involved the government without going through a peace model that is based on local culture which has been used as a reference for Christian and Muslim society before the social conflict in 1999. Therefore, the effort to create peace through reconciliation continues between Christian and Muslim to create true peace between them, so the question is how the peace model between Christian and Muslim in Tehoru and Telutih Districts based on local culture after the 1999 conflict? In order can establish a model of peace between Christian and Muslim in Telutih and Tehoru Districts based on local culture.

The study about peace continues to be done to create peace in society, Moh. Nutfa and Sakaria Anwar studied about rebuilding peace: Reconciliation of trust-based communal conflict, illustrated that peace can be realized and it must be preceded by the existence of trust in society / communal life. ${ }^{2}$ While Taat Wulandari studied about creating peace through peace education in school. It is illustrated that the various conflicts occurred in Indonesia can be overcome by various knowledge about the condition of Indonesian nation from early age, so education is

\footnotetext{
${ }^{1}$ Resa Dandirwalu, "Totem Ambon Manise: Membongkar Segregasi Teritorial Berbasis Agama Di Kota Ambon," Antropologi Indonesia; Indonesian Journal of Social and Cultural Anthropology 35, no. 1 (2014): 31., http://journal.ui.ac.id/index.php/jai/-article/view/5511/3534.

${ }^{2}$ Moh. Nutfa dan Sakaria Anwar, "Membanguyn Kembali Perdamaian: Rekonsiliasi Konflik Komunal Berbasis Trust," Jurnal Kritis. Vol. 1 No. 1, July 2015. http://journal.unhas.ac.id/index.php/kritis/article/view/8/8
} 
used as the media to form attitude of peace. ${ }^{1}$ Meanwhile, Tirsa Budiarti studied about models of peace education for children in the context of the church. The result showed that knowledge of peace for children from early age can contribute so they can become agents of peace in the future, so the church is the media and model in transferring knowledge of peace. ${ }^{2}$ Other researcher, CB. Mulyatno studied about philosophizing as a movement to create the peace world. According to Eric Weil, the result showed that peace can be realized if the action of the society go to the ratio accompanied by high morality of a community. ${ }^{3} \mathrm{Hj}$. Nurul Azizah studied about the role of Islamic education in realizing justice and peace in Indonesia. It is illustrated if Islamic education is given properly and correctly to someone, the life of the recipient of knowledge will be organized and directed. ${ }^{4}$

This research used qualitative method, observation and in-depth interview used as field data collection techniques, qualitative analysis is used as analysis tool and this research is located in Tehoru and Telutih Districts.

The purpose of this article is to spread good insight and as the reference for the society that local culture is very relevant and operational to be used as an alternative model in creating and realizing peace in the life of diverse society in the Maluku Province and the Unitary State of the Republic of Indonesia, so society can have security and comfortable live.

\section{B. FINDING AND DSCUSSION}

\section{Statistics on Muslim, Christian, and Catholic Population in Maluku Province}

atistical data from the Central Statistics Agency (BPS) of Maluku Province in 2018, in 11 regencies / cities, regarding the Muslim, Christian and Catholic population are

a. West Southeast Maluku Regency. Islam: 10,72; Christian: 81,80; Catholic: 7,18

b. Maluku Regency. Islam: 33,86; Christian: 20,43; Catholic: 44,72

c. Central Maluku Regency: Islam: 54,53; Christian: 40,90; Catholic: 3,49

d. Buru Regency: Islam: 94,28; Christian: 0,34; Catholic: 0,19

e. Aru Island Regency. Islam: 37,54; Christian: 50,47; Catholic: 11,67

f. West Seram Regency. Islam: 66,26; Christian: 32,53; Catholic: 1,13

g. East Seram Regency. Islam: 93,75; Christian: 2,93; Catholic: 2,34

h. Southwest Maluku Regency. Islam: 1,75; Christian: 94,11; Catholic: 3,97

i. South Buru Regency. Islam: 23,06; Christian: 65,80; Catholic: 0,48

j. Ambon City. Islam: 52,69; Christian: 41,29; Catholic: 5,84

k. Tual City. Islam: 77,33; Christian: 15,77; Catholic: $6,82 .{ }^{5}$

The data above shows that the majority of the population in Central Maluku Regency is Muslim, followed by Christian and Catholic, so the Regent in Central Maluku Regency is always Muslim, in order to balance out the majority of the Muslim population.

\section{The Overview of Tehoru and Telutih Districts}

Tehoru district is part of the Central Maluku Regency which is located in the South of Seram Island and transportation uses to travel from the Capital City of Central Maluku Regency to the Capital City of Tehoru District across the land by motorized vehicle with a distance of less than $100 \mathrm{~km}$. The total area of the Tehoru District is $405.72 \mathrm{~km}^{2}$ which is divided into 10 villages, namely: Salamahu, Haya, Tehoru, Yaputih, Mosso, Telutih Baru, Saunulu, Piliana, Hatu, and Hatumeten. Then the population based on religion are: Muslim: 17.271 people; Christian: 4.195 people; Catholic: 36 people, and Hindu: 10 people. $^{6}$

While Telutih District is one of the regions in Central Maluku Regency and it is located in the south of Seram Island. The distance from Masohi, the Capital City of Central Maluku Regency is less than $200 \mathrm{~km}$ by using land

\footnotetext{
${ }^{1}$ Taat Wulandari, "Menciptakan Perdamaian Melalui Pendidikan Perdamaian Di Sekolah,” Jurnal MOZAIK, vol. V, no. 1, January 2010 https://journal.uny.ac.id > mozaik > article > download

2 Tirsa Budiarti. Model-Model Pendidikan Perdamaian Bagi Anak Dalam Konteks Gereja. Jurnal Jaffray. Vol 16, No 1 (2018. https://ojs.sttjaffray.ac.id/index.php/JJV71/article/view/280/pdf 169.

${ }^{3}$ CB. Mulyatno. berfilsafat sebagai gerakan mewujudkan perdamaian dunia menurut Eric Weil. Jurnal ORIENTASI BARU, VOL. 19, NO. 2, OCTOBER 2010

https://e-journal.usd.ac.id > job > article > download

${ }^{4}$ Hj. Nurul Azizah, Peran Pendidikan Agama Islam Dalam Mewujudkan Keadilan dan Perdamaian di Indonesia. Jurnal Cendekia Vol 11 No2 Th 2013.

Https://Jurnal.Iainponorogo.Ac.Id > Article > Download

5 Central Bureau of Statistics in Maluku Regency., "Provinsi Maluku Dalam Angka 2018." https://maluku.bps.go.id/publication/download.html?nrbvfeve=ZmYxZjUyYmRiZDFiNTkzOGQ1ZWY2MjA2\&xzmn=aHR0cHM6Ly9tY Wx1a3UuYnBzLmdvLmlkL3B1YmxpY2F0aW9uLzIwMTgvMDgvMTYvZmYxZjUyYmRiZDFiNTkzOGQ1ZWY2MjA2L3Byb3ZpbnNp LW1hbHVrdS1kYWxhbS1hbmdrYS0yMDE4Lmh0bWw\%3D\&twoadfnoarfeauf=MjAxOS0xMC0xNyAxNzo0Mzo0Ng\%3D\%3D

6 Central Bureau of Statistics in Central Maluku Regency, "Kecamatan Tehoru Dalam Angka Tahun 2018." https://malukutengahkab.bps.go.id/publication/download.html?nrbvfeve=ZjUxNGMzMTBkNDBlOWJhZGVjMTc3Y2Qx\&xzmn=aHR0cH M6Ly9tYWx1a3V0ZW5nYWhrYWIuYnBzLmdvLmlkL3B1YmxpY2F0aW9uLzIwMTgvMDkvMjYvZjUxNGMzMTBkNDB1OWJhZGVj MTc3Y2QxL2tlY2FtYXRhbi10ZWhvcnUtZGFsYW0tYW5na2EtMjAxOC5odG1s\&twoadfnoarfeauf=MjAxOS0wOS0yNiAxNjowNToxO $\mathrm{Q} \% 3 \mathrm{D} \% 3 \mathrm{D}$
} 
vehicle. Geographically, Telutih District is bordered by: North side is bordered by North Seram District, south side is bordered by Banda sea, west side is bordered by Telutih District and east side is bordered by East Seram District. Telutih District consists of 11 villages, namely: Wolu, Lafa, Tehua, Maneoratu, Laimu, Hunisi, Yamalatu, Laha, Lahakaba, Ulahahan. Furthermore, the population is based on religion, namely: Muslim: 9.504 people; Christian: 2.997 people; and Catholic: 17 people. $^{1}$

Based on the data of the number of residents based on religious adherents found in Tehoru and Telutih districts, it appears that the majority are Muslim.

\section{Tahuri: The model of Christian and Muslim peace based on local culture}

True peace after conflict becomes the desire of every individual, so sustainability of life can take place safely and comfortably without being based on worry, fear, suspicion, and revenge, as stated by Taat Wulandari that peace is safe and harmonious situation, ${ }^{2}$ then efforts continue to be made by various parties to make it happen.

The peace model after the 1999 social conflict in Maluku, especially in Tehoru and Telutih districts became something important to do, so tahuri became a model of peace for Christian and Muslim based on local culture. Local culture has different concept among experts who study about it. There are experts who conceptualize that local culture is an expression of the culture of society in the past; local culture is the cultural identity of a society that is able to survive from the presence of outside culture; and local culture is a human and community policy towards natural resources that contain philosophical and normative values to maintain behavior for the sake of living together, ${ }^{3}$ and believe in its truth, ${ }^{4}$ so as to create a healthy, comfortable, and harmonious life in interacting with others, ${ }^{5}$ Local culture can be actualized through symbols together with a community and sacred through various rituals, in order to have the strength to survive and to unite the community that holds the cultural symbol. Tahuri is one of the symbols of the local culture of Souupaa Maraina - Nunu Saku, which is made from seashell skin or bia skin in the name of the Ambonese community (Maluku), ${ }^{6}$ with the literal meaning is a long sound. ${ }^{7}$ Therefore, tahuri must be sounded by blowing, so it requires the ability to process breathing from sipeniup, as shown in Figure 1.

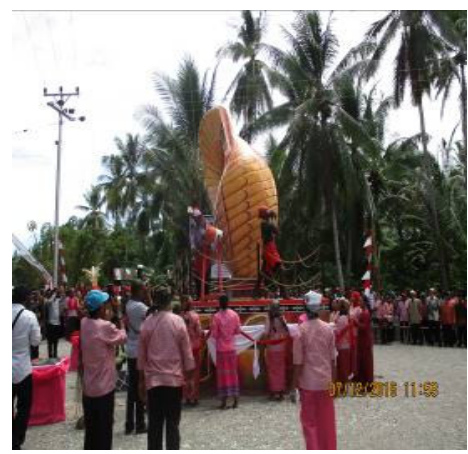

Figure 1

How to Blow Tahuri

(Photo by: Handry Yance Rehy, 2016)

Tahuri is a cultural symbol that is usually used in every traditional ritual performed by the society, such as the heat of pela-gandong, inauguration of the king and washing the country (cuci negeri). It placed at the beginning of the ritual with the intention is to invite the public to attend traditional ritual that is held and as the beginning of the implementation of traditional ritual, as well as inviting ancestors (Lahatala) and all deceased relatives to attend and accompany the implementation of ongoing traditional ritual, so the process can proceed smoothly and have a

\footnotetext{
Central Bureau of Statistics in Central Maluku Regency, "Kecamatan Telutih Dalam Angka Tahun 2018." https://malukutengahkab.bps.go.id/publication/download.html?nrbvfeve=MzhlNzQxOTJmZWM3ZWY0MGJiMzE0OTc1\&xzmn=aHR0cH M6Ly9tYWx1a3V0ZW5nYWhrYWIuYnBzLmdvLmlkL3B1YmxpY2F0aW9uLzIwMTgvMDkvMjYvMzhlNzQxOTJmZWM3ZWY0MGJi MzE0OTc1L2tlY2FtYXRhbi10ZWx1dGloLWRhbGFtLWFuZ2thLTIwMTguaHRtbA\%3D\%3D\&twoadfnoarfeauf=MjAxOS0wOS0yNiAx NjoyMjowMA\%3D\%3D

2 Taat Wulandari, "Menciptakan Perdamaian Melalui Pendidikan Perdamaian Di Sekolah."

3 Ida Bagus Brata, "Kearifan Budaya Lokal Perekat Identitas Bangsa," Jurnal Bakti Saraswati, vol. 05, no.01. March 2016. https://media.neliti.com/media/publications/75588-ID-kearifan-budaya-lokal-perekat-identitas.pdf

${ }^{4}$ Sulaiman, "Rekonsiliasi Berbasis Kearifan Lokal Di Aceh,” Kanun Jurnal Ilmu Hukum, vol. 18, No. 3, (December, 2016$)$, p. $367-376$. jurnal.unsyiah.ac.id, kanun, article , download

${ }^{5}$ N. Hidayat, "Nilai-Nilai Ajaran Islam Tentang Perdamaian (Kajian Antara Teori dan Praktek)," Aplikasia; Jurnal Aplikasi Ilmu-ilmu Agama, vol. 17, no. 1, 2017.

ejournal.uin-suka.ac.id/pusat/aplikasia

${ }^{6}$ Fridolin L. Muskitta, "Kehidupan Musik Tahurimasyarakat Negeri Hutumuri, Kecamatan Leitimur Selatan, Kotamadya Ambon Dalam konteks Budaya," Jurnal Ekspresi Seni, vol. 17, no. 1, Juni 2015. https://media.neliti.com/media/publications/89956-ID-kehidupan-musiktahuri-masyarakat-negeri.pdf

${ }^{7}$ Result of interview conducted on 25 September, with Mr. Christian Izaak Tamaela (Lecturer at Faculty of Theology, UKIM Ambon) at the office of Faculty of Theology, UKIM Ambon.
} 
positive impact (blessing) on the communities and villages involved in it.

Based on the result of the research conducted in Tehoru and Telutih Districts, the information obtained is that Tahuri is made a model of peace for Christian and Muslim in Tehoru and Telutih Districts because it has a deep meaning, namely: first, tahuri is used as a symbol of identity as well as community social cohesion (collective) in villages in Tehoru and Telutih Districts; secondly, the symbol of the partnership of the Basudara (brotherhood) ade-kaka (brother and sister); and third, the symbol of responsibility.

a. Tahuri as the Symbol of Identity as well as Social Cohesion

Based on the results of interviews with King of Wolu Village (Muslim), King of Laimu Village (Muslim), King of Tehua Village (Muslim), King of Lafa Village (Christian), King of Laha Village (Christian), King of Yaputih Village (Muslim), Secretary of Protestant church of maluku of Telutih Class (Christian), the information obtained that "since a long time ago, parents have used tahuri during traditional ritual and all of the society already knew that when tahuri was rung means the community would gather to participate in traditional activities to be carried out, so current generation is familiar with tahuri." The description above indicates that tahuri is a symbol of identity as well as social cohesion ${ }^{1}$ for the society, in social interaction between Christian and Muslim is to create a harmonious order of life without distinguishing certain statuses in society because the priority lies in tahuri as a collective symbol as well as social cohesion.

For the affirmation of the symbol of identity as well as social cohesion, Tahuri monument was made in the Land of Lafa (Christian), as shown in figure 2, and the election of the Lafa village as the location of the Tahuri monument was based on cultural history story that the village is the mother of all villages in Tehoru and Telutih Districts.

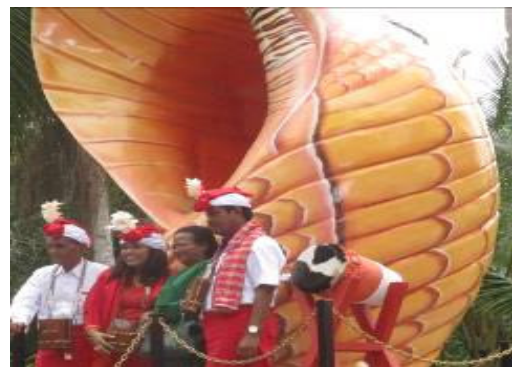

Figure 2

Inauguration of Tahuri Monument

(Photo by: Handry Yance Rehy, 2016)

This assertion showed the value of morality and solidarity to preserve the symbols in collective life of the society, thus creating a shared awareness about the importance of collective identity while producing social cohesion in relation between Christian and Muslim, so the researcher disagreed with the opinions expressed by Moh. Nutfa and Sakaria Anwar, that reconciliation has failed because it has not been able to restore the social capital of the society that have been ravaged or lost due to communal conflict, ${ }^{2}$ because tahuri is still used as a symbol of identity as a form of social capital in creating peace between Christian and Muslim in Tehoru and Telutih Districts to build their religious life. ${ }^{3}$

Based on the information that researcher obtained from the public that "at the time of the Presidential Election, DPR RI, DPRD, DPRD for Regency in 2019, the issue of religion could not destroy the current order of society life." It showed that Christian and Muslim in Tehotu and Telutih Districts were very understanding tahuri symbol rather than issues of community disintegration.

\section{b. Tahuri, The Symbol of Ade-Kaka Basudara Partnership (Brotherhood and Sisterhood)}

For Christian and Muslim in Tehoru and Telutih districts, tahuri is a symbol of the partnership of Basudara (brotherhood) because through them the community is gathered in one alliance through traditional ritual regardless of certain social status. As stated by King of Wolu village (Muslim), King of Laimu village (Muslim), King of Negeriua village (Muslim),King of Lafa village (Christian), King of Laha village (Christian), King of Yaputih village (Islam ), Secretary of Protestant church of maluku of Telutih Class (Christian), that "the community will gather when they hear the voice of tahuri, because they already know that adat rituals will be carried out, so they will surely be present to celebrate." A similar opinion was also conveyed by Mr. Zainal Yaplalin (Muslim), Mrs. Hasmi Tehuayo (Muslim), Mr. Menase Tamala (Christian), that "Christian and Muslim already known that the sound of tahuri always leads them to gather in traditional ritual conducted."

The informant data above showed that through tahuri, Christian and Muslim are continue to create a

${ }^{1}$ Resa Dandirwalu, "Totem Ambon Manise: Membongkar Segregasi Teritorial Berbasis Agama Di Kota Ambon.

${ }^{2}$ Moh. Nutfa dan Sakaria Anwar, "Membanguyn Kembali Perdamaian: Rekonsiliasi Konflik Komunal Berbasis Trust."

${ }^{3}$ Stephanus Turibius Rahmat. Dialog Antropologis Antaragama Dengan Spiritualitas Passing Over,"

Wawasan: Jurnal Ilmiah Agama dan Sosial Budaya, vol. 2, no. 2 (December

2017). 
harmonious and safe atmosphere to eliminate suspicion among them after the conflict. A sign that tahuri gives them the power to act as ade-kaka basudara partnership and has the perception that no one can separate the adekaka basudara partnership, so the solution to the problem can only be resolved by themselves and not by other parties. ${ }^{1}$ Therefore the call of "acang" (for Muslim) and "obet" (for Christian) do not become a reality in society to have relation between Christian and Muslim. An example is the traditional ritual of the Tahuri monument which inauguration shows the partnership that is related between Christian and Muslim.

The partnership that is established between Christian and Muslim through traditional ritual is increasingly influenced by the sacredness that is created in it, because it involves ancestor (luluhur/Lahatala) and parents who have died, so the sanctity of the life of the basudara ade-kaka is based on the value of sacredness, it shown in figure 3 .

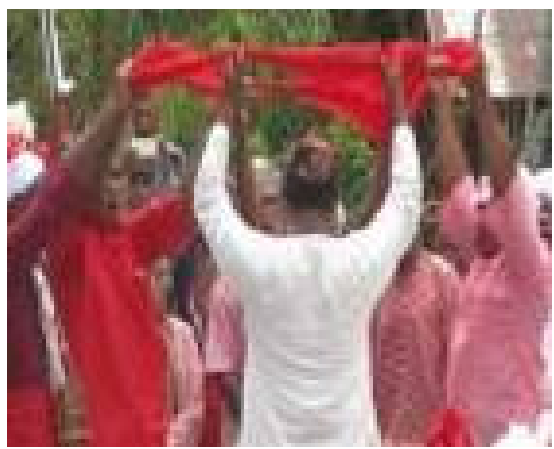

Figure 3

Customary Ritual of Tahuri Inauguration Monument

(Photo by: Handry Yance Rehy, 2016)

\section{c. Tahuri Symbol of Responsibility}

The responsibility to maintain and continue the peace created between Christian and Muslim in Tehoru and Telutih districts is the implementation of the value of "continuing the message" contained in tahuri. As stated by King of Wolu village (Muslim), King of Laimu village (Muslim), King of Negeriua village (Muslim), King of Lafa village (Christian), King of Laha village (Christian), King of Yaputih village (Islam), Secretary of Protestant church of maluku of Telutih Class (Christian), that "the peace that we create between Christian and Muslim does not belong to us only, but must be passed on to our children and grandchildren and other society." This view means that building a peaceful life is a responsibility that is carried out by each individual and community continuously because according to CB Mulyatno every human being is a creature of peace dialogue, so the rational and human life is the duty of every individual continuously. ${ }^{2}$

The responsibility to maintain and continue the peace is expressed through acceptance of Christian students from Christian University of Indonesia, Maluku to live together for 6 weeks with Muslims in Muslim villages such as in Yaputih, Wolu, Tehua, Laimu, and Lahakaba. This responsibility is also expressed through the involvement of Muslims in supporting ecclesiastical activities and also the involvement of Christians in supporting Islamic activities as shown in Figure 4.

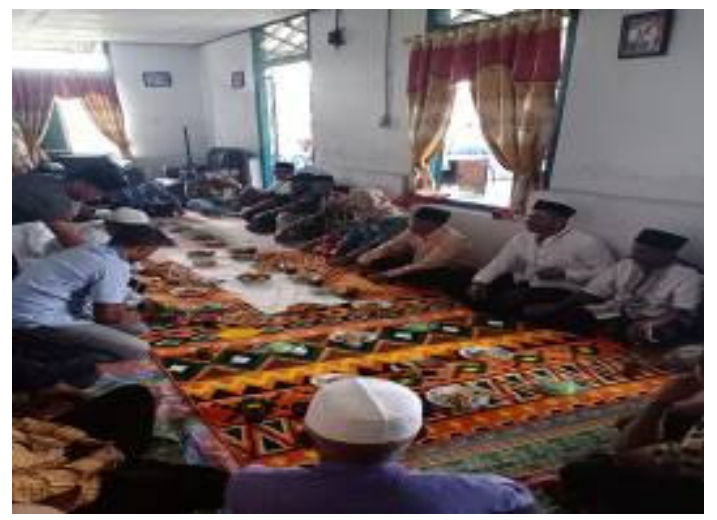

Figure 4

Circumcision Event in Wolu Village

(Photo by: Resa Dandirwalu, 2019)

\footnotetext{
${ }^{1}$ Noor Haliemah dan Rama Kertamukti, “Interaksi Simbolis Masyarakat Dalam Memaknai Kesenian Jathilan,” Jurnal ASPIKOM, vol. 3, no. 3, July 2017.

jurnalaspikom.org > aspikom > article > download

${ }^{2}$ CB. Mulyatno, "Berfilsafat Sebagai Gerakan Mewujudkan Perdamaian Dunia Menurut Eric Weil."
} 


\section{CONCLUSION}

Post-conflict peace became important for Christian and Muslim in Tehoru and Telutih districts to live together without anxious and fear, so the effort to realize was through a relevant peace model, which was based on the local culture of the community which was used as the norm of living together in society. The local culture was tahuri because for Christian and Muslim in Tehoru and Telutih Districts, tahuri has a deep meaning, namely: first, tahuri was used as a symbol of identity as well as community (collective) social cohesion in villages in Tehoru and Telutih Districts; secondly, tahuri was as a symbol of the brotherhood of basudara (brotherhood) ade-kaka (brotherhood and sisterhood); and third, tahuri was as a symbol of responsibility.

\section{REFERENCES}

Azizah Nurul HJ, Peran Pendidikan Agama Islam Dalam Mewujudkan Keadilan dan Perdamaian di Indonesia. Jurnal Cendekia Vol. 11 No. 2, 2013.

Https://Jurnal.Iainponorogo.Ac.Id > Article > Download

Budiarti Tirsa. Model-Model Pendidikan Perdamaian Bagi Anak Dalam Konteks Gereja. Jurnal Jaffray. Vol 16, No 1 (2018. https://ojs.sttjaffray.ac.id/index.php/JJV71/article/view/280/pdf_169.

Central Bureau of Statistics in Maluku Regency, "Provinsi Maluku Dalam Angka 2018." https://maluku.bps.go.id/publication/download.html?nrbvfeve=ZmYxZjUyYmRiZDFiNTkzOGQ1ZWY2M jA2\&xzmn=aHR0cHM6Ly9tYWx1a3UuYnBzLmdvLmlkL3B1YmxpY2F0aW9uLzIwMTgvMDgvMTYv ZmYxZjUyYmRiZDFiNTkzOGQ1ZWY2MjA2L3Byb3ZpbnNpLW1hbHVrdS1kYWxhbS1hbmdrYS0yM DE4Lmh0bWw\%3D\&twoadfnoarfeauf=MjAxOS0xMC0xNyAxNzo0Mzo0Ng\%3D\%3D

Central Bureau of Statistics in Central Maluku Regency, "Kecamatan Tehoru Dalam Angka Tahun 2018." https://malukutengahkab.bps.go.id/publication/download.html?nrbvfeve=ZjUxNGMzMTBkNDBlOWJhZG VjMTc3Y2Qx\&xzmn=aHR0cHM6Ly9tYWx1a3V0ZW5nYWhrYWIuYnBzLmdvLmlkL3B1YmxpY2F0a W9uLzIwMTgvMDkvMjYvZjUxNGMzMTBkNDB1OWJhZGVjMTc3Y2QxL2tlY2FtYXRhbi10ZWhven UtZGFsYW0tYW5na2EtMjAxOC5odG1s\&twoadfnoarfeauf=MjAxOS0wOS0yNiAxNjowNToxOQ\%3D\% $3 \mathrm{D}$

Central Bureau of Statistics in Central Maluku Regency, "Kecamatan Telutih Dalam Angka Tahun 2018." https://malukutengahkab.bps.go.id/publication/download.html?nrbvfeve=MzhlNzQxOTJmZWM3ZWY0M GJiMzE0OTc1\&xzmn=aHR0cHM6Ly9tYWx1a3V0ZW5nYWhrYWIuYnBzLmdvLmlkL3B1YmxpY2F0a W9uLzIwMTgvMDkvMjYvMzhlNzQxOTJmZWM3ZWY0MGJiMzE0OTc1L2tlY2FtYXRhbi10ZWx1dG loLWRhbGFtLWFuZ2thLTIwMTguaHRtbA\%3D\%3D\&twoadfnoarfeauf=MjAxOS0wOS0yNiAxNjoyMjo wMA $\% 3 \mathrm{D} \% 3 \mathrm{D}$

Brata Bagus Ida, "Kearifan Budaya Lokal Perekat Identitas Bangsa,” Jurnal Bakti Saraswati, vol. 05, no.01. Maret 2016. https://media.neliti.com/media/publications/75588-ID-kearifan-budaya-lokal-perekat-identitas.pdf

Dandirwalu Resa, "Totem Ambon Manise: Membongkar Segregasi Teritorial Berbasis Agama Di Kota Ambon," Antropologi Indonesia; Indonesian Journal of Social and Cultural Anthropology 35, no. 1 (2014): 31. ,, http://journal.ui.ac.id/index.php/jai/-article/view/5511/3534.

Hidayat N, "Nilai-Nilai Ajaran Islam Tentang Perdamaian (Kajian Antara Teori dan Praktek)," Aplikasia; Jurnal Aplikasi Ilmu-ilmu Agama, vol. 17, no. 1, 2017.

ejournal.uin-suka.ac.id/pusat/aplikasia

Haliemah Noor dan Rama Kertamukti, "Interaksi Simbolis Masyarakat Dalam Memaknai Kesenian Jathilan," Jurnal ASPIKOM, vol. 3, no. 3, July 2017.

jurnalaspikom.org > aspikom > article > download

Result of interview conducted on 25 September with Mr. Christian Izaak Tamaela (Lecturer at Fakulty of Theology, UKIM Ambon) at the office of Fakulty of Theology, UKIM Ambon.

Mulyatno CB, "Berfilsafat Sebagai Gerakan Mewujudkan Perdamaian Dunia Menurut Eric Weil," Jurnal Orientasi Baru, vol. 19, no. 2, October 2010

https://e-journal.usd.ac.id > job > article > download

Muskita L. Fridolin, "Kehidupan Musik Tahurimasyarakat Negeri Hutumuri, Kecamatan Leitimur Selatan, Kotamadya Ambon Dalam konteks Budaya," Jurnal Ekspresi Seni, vol. 17, no. 1, June 2015. https://media.neliti.com/media/publications/89956-ID-kehidupan-musik-tahuri-masyarakat-negeri.pdf

Nutfa Moh dan Sakaria Anwar, "Membanguyn Kembali Perdamaian: Rekonsiliasi Konflik Komunal Berbasis Trust," Jurnal Kritis. Volume $1 \quad$ Number $1, \quad$ July 2015. http://journal.unhas.ac.id/index.php/kritis/article/view/8/8

Rahmat Turibius Stephanus, "Dialog Antropologis Antaragama Dengan Spiritualitas Passing Over,"

Wawasan: Jurnal Ilmiah Agama dan Sosial Budaya, vol. 2, no. 2 (December 2017). https://journal.uinsgd.ac.id/index.php/jw/article/view/1704/1378

Sulaiman, "Rekonsiliasi Berbasis Kearifan Lokal Di Aceh,” Kanun Jurnal Ilmu Hukum, vol. 18, No. 3, (December, 2016), p. 367-376. jurnal.unsyiah.ac.id > kanun > article > download 
Wulandari Taat, "Menciptakan Perdamaian Melalui Pendidikan Perdamaian Di Sekolah," Jurnal MOZAIK, volume V, no.1, January 2010

https://journal.uny.ac.id $>$ mozaik $>$ article $>$ download 